\title{
Molecular Identification of Anisakis Larvae Extracted by Gastrointestinal Endoscopy from Health Check-up Patients in Korea
}

\author{
Hyemi Song', Bong-Kwang Jung', Jaeeun Cho', Taehee Chang', Sun Huh², Jong-Yil Chai ${ }^{1,3, *}$ \\ IInstitute of Parasitic Diseases, Korea Association of Health Promotion, Seoul 07649, Korea; ${ }^{2}$ Department of Parasitology and Institute of Medical \\ Education, Hallym University College of Medicine, Chuncheon 24252, Korea; ${ }^{3}$ Department of Tropical Medicine and Parasitology, Seoul National \\ University College of Medicine, Seoul 03080, Korea
}

\begin{abstract}
Anisakiasis is a zoonotic disease induced by anisakid nematodes, and endoscopic inspection is used for a diagnosis or remedy for it. Anisakis simplex, Anisakis physeteris, and Pseudoterranova decipiens had been reported to be the major species causing human infections, particularly, in Japan. However, in Korea, recent studies strongly suggested that Anisakis pegreffii is the major species of human infections. To support this suggestion, we collected anisakid larvae $(n=20)$ from 20 human patients who were undergone gastrointestinal endoscopy at a health check-up center in Korea, and molecular identification was performed on the larvae using PCR-RFLP analysis and gene sequencing of rDNA ITS regions and mtDNA cox2. In addition, anisakid larvae $(n=53)$ collected from the sea eel (Astroconger myriaster) were also examined for comparison with those extracted from humans. The results showed that all human samples (100\%) were identified as $A$. pegreffii, whereas $90.7 \%$ of the samples from the sea eel were $A$. pegreffii with the remaining $9.3 \%$ being Hysterothylacium aduncum. Our study confirmed that $A$. pegreffii is the predominant species causing human anisakiasis in Korea, and this seems to be due to the predominance of this larval type in the fish (sea eels) popularly consumed by the Korean people. The possibility of human infection with $\mathrm{H}$. aduncum in Korea is also suggested.
\end{abstract}

Key words: Anisakis pegreffii, Anisakis simplex sensu stricto, Hysterothylacium aduncum, anisakiasis, anisakid larva, gastrointestinal endoscopy, sequencing, internal transcribed spacer (ITS), cox2

Trends of parasitic diseases in the Republic of Korea (= Korea) have remarkably changed. In particular, the prevalence of soil-transmitted nematodes has been successfully controlled to become very low; however, foodborne parasitic infections are still prevalent in Korea [1].

Anisakiasis is a foodborne zoonotic infection contracted mainly by the larval nematodes of the genera Anisakis and Pseudoterranova after consuming raw or undercooked parasitized fish or squids. Three species, Anisakis simplex, Anisakis physeteris, and Pseudoterranova decipiens, have been reported to be the main etiological agents of human infections, particularly, in Japan [2]. The clinical symptoms include abdominal pain, nausea, and vomiting, and the larvae can be removed at gastrointestinal endoscopy or by surgery $[3,4]$. Although the diag-

\footnotetext{
- Received 27 February 2019, revised 14 April 2019, accepted 14 April 2019.

*Corresponding author (cjy@snu.ac.kr)

(C) 2019, Korean Society for Parasitology and Tropical Medicine

This is an Open Access article distributed under the terms of the Creative Commons

Attribution Non-Commercial License (http://creativecommons.org/licenses/by-nc/4.0)

which permits unrestricted non-commercial use, distribution, and reproduction in any

medium, provided the original work is properly cited.
}

nosis is generally made by endoscopic inspections to recover the larvae, the species-specific identification is difficult only by the larval morphology, in which case molecular approaches are essential.

In Korea, there are several studies on the species identification of anisakid larvae collected from human patients. Based on morphological characteristics, between 1989 and 1992, Im et al. [5] reported A. simplex (Anisakis type I larvae) to be the major species (91.1\%) among 90 samples that infected humans [5]. Other reports described that A. simplex (Anisakis type I larvae) and $P$. decipiens (Pseudoterranova type A larvae) were the main species causing human anisakiasis in Korea [6,7]. Recently, however, using molecular techniques, Lim et al. [8] reported that 25 of 26 samples collected from 16 human infections during 2000-2013 in Korea were identified as Anisakis pegreffii, and only 1 sample was A. simplex [8]. Both of these species have similar morphologies in their larval stages (Anisakis type I larvae) from fish hosts [8]. Therefore, molecular analyses are strongly recommended to make the specific diagnosis of, in particular, A. simplex sensu stricto (s.s.) and A. pegreffii [2]. 
As the traditional habits of eating raw seafood have been maintained in Korea, we need to know the latest tendencies of anisakid larvae occurring in humans and fish (and squids) in Korea. In this study, we carried out molecular studies for a specific diagnosis of anisakid larvae extracted by gastrointestinal endoscopy of health check-up patients in Korea and also of anisakid larvae collected from the sea eel (Astroconger myriaster) which is popularly eaten by the people and known to be an important source of human anisakiasis in Korea [2].

A total of 20 nematodes or nematode fragments extracted from the stomach $(n=19)$ or large intestine $(n=1)$ of 20 health check-up patients through endoscopy were referred to the Institute of Parasitic Diseases, Korea Association of Health Promotion, Seoul, Korea, during 2017-2019 for specific diagnosis (Table 1). All of these samples were morphologically diagnosed as anisakiasis (Anisakis type I larvae) having a boring tooth and a mucron. In order to obtain a specific diagnosis, the total genomic DNA was isolated from the 20 nematode specimens using a DNeasy Blood and Tissue Kit (Qiagen, Hilden, Germany) according to the manufacturer's instructions. In addition, we also examined 54 larval nematode samples collected from the sea eel for comparison with those from human infections.
Molecular identification was performed using PCR-RFLP and sequencing of nuclear ribosomal and mitochondrial genes. We amplified the nuclear ribosomal DNA (rDNA), internal transcribed spacer (ITS) region, with primers ITS A (5'GTC GAA TTC GTA GGT GAA CCT GCG GAA GGA TCA-3') and ITS B (5'-GCC GGA TCC GAA TCC TGG TTA GTT TCT TTT CCT-3') [9] using $2 \times$ MasterMix (MGmed, Seoul, Korea) under initial denaturation for $10 \mathrm{~min}$ at $95^{\circ} \mathrm{C}$ and 30 cycles of denaturation for $30 \mathrm{sec}$ at $95^{\circ} \mathrm{C}$, annealing for $30 \mathrm{sec}$ at $55^{\circ} \mathrm{C}$, extension for $75 \mathrm{sec}$ at $72^{\circ} \mathrm{C}$ and final extension for $7 \mathrm{~min}$ at $72^{\circ} \mathrm{C}$. The mitochondrial DNA (mtDNA), cytochrome $c$ oxidase 2 (cox2), was amplified using the primers 211F (5'-TTT TCT AGT TAT ATA GAT TGG TTC AT-3') and 210R (5'-CAC CAA CTC TTA AAA TTA TC-3') [10] under initial denaturation for $2 \mathrm{~min}$ at $95^{\circ} \mathrm{C}$ and 32 cycles of denaturation for $30 \mathrm{sec}$ at $95^{\circ} \mathrm{C}$, annealing for $30 \mathrm{sec}$ at $48^{\circ} \mathrm{C}$, extension for $60 \mathrm{sec}$ at $72^{\circ} \mathrm{C}$, and final extension for 7 min at $5^{\circ} \mathrm{C}$.

Each ITS PCR product was digested overnight at $37^{\circ} \mathrm{C}$ with Hinfl restriction endonuclease (Enzynomics, Daejeon, Korea) and $10 \times$ EZ-one buffer (Enzynomics). The restriction fragment patterns were separated by electrophoresis on $2 \%$ agarose gels stained with StaySafe ${ }^{\mathrm{TM}}$ Nucleic Acid Gel Stain (Real Biotech Corporation, Taipei, Taiwan) and visualized using illumina-

Table 1. Identification of Anisakis larvae extracted by gastrointestinal endoscopy from health checkup patients using gene sequencing

\begin{tabular}{|c|c|c|c|c|c|c|c|c|c|}
\hline & \multirow{2}{*}{$\begin{array}{c}\text { Type of } \\
\text { endoscopy }\end{array}$} & \multirow{2}{*}{$\begin{array}{c}\text { Date of } \\
\text { extraction }\end{array}$} & \multirow{2}{*}{$\begin{array}{l}\text { Patient } \\
\text { sex/age }\end{array}$} & \multicolumn{3}{|c|}{ ITS region } & \multicolumn{3}{|c|}{ Cox2 } \\
\hline & & & & $\begin{array}{c}\text { A. pegreffii } \\
\text { (AB277823) }\end{array}$ & $\begin{array}{c}\text { A. simplex } \\
\text { (AB277822) }\end{array}$ & $\begin{array}{c}\text { A. typica } \\
\text { (AY826724) }\end{array}$ & $\begin{array}{l}\text { A. pegreffii } \\
\text { (EU413958) }\end{array}$ & $\begin{array}{c}\text { A. simplex } \\
\text { (AB517560) }\end{array}$ & $\begin{array}{c}\text { A. typica } \\
(\mathrm{AB} 517571)\end{array}$ \\
\hline Sample 1 & Gastroscopy & Jan. 2019 & F/66 & 100 & 99.4 & 76.7 & 97.9 & 96.3 & 86.5 \\
\hline Sample 2 & Gastroscopy & May. 2018 & $F / 51$ & 100 & 99.4 & 76.7 & - & - & - \\
\hline Sample 3 & Gastroscopy & Jun. 2018 & $F / 66$ & 100 & 99.4 & 76.7 & - & - & - \\
\hline Sample 5 & Gastroscopy & Jun. 2018 & $F / 47$ & 100 & 99.4 & 76.7 & - & - & - \\
\hline Sample 6 & Gastroscopy & Jun. 2018 & $\mathrm{M} / 61$ & 100 & 99.4 & 76.7 & - & - & - \\
\hline Sample 7 & Gastroscopy & Aug. 2018 & $M / 55$ & 100 & 99.4 & 76.7 & 99.7 & 95.5 & 86.5 \\
\hline Sample 8 & Gastroscopy & Aug. 2018 & M/69 & 100 & 99.4 & 76.7 & 100.0 & 95.2 & 86.2 \\
\hline Sample 9 & Gastroscopy & Sep. 2018 & $M / 67$ & 100 & 99.4 & 76.7 & 98.1 & 96.6 & 86.8 \\
\hline Sample 10 & Gastroscopy & Sep. 2018 & $\mathrm{M} / 57$ & 100 & 99.4 & 76.7 & - & - & - \\
\hline Sample 12 & Gastroscopy & Sep. 2018 & $F / 56$ & 100 & 99.4 & 76.7 & 99.7 & 95.0 & 86.0 \\
\hline Sample 13 & Gastroscopy & Oct. 2018 & $\mathrm{~F} / 56$ & 100 & 99.4 & 76.7 & 97.9 & 96.3 & 86.5 \\
\hline Sample 14 & Gastroscopy & Oct. 2018 & $M / 44$ & 100 & 99.4 & 76.7 & 100.0 & 95.2 & 86.2 \\
\hline Sample 15 & Gastroscopy & Nov. 2018 & $\mathrm{M} / 61$ & 100 & 99.4 & 76.7 & 99.7 & 95.0 & 86.2 \\
\hline Sample 16 & Gastroscopy & Nov. 2018 & $\mathrm{~F} / 69$ & 100 & 99.4 & 76.7 & 100.0 & 95.2 & 86.2 \\
\hline Sample 17 & Gastroscopy & Nov. 2018 & $F / 45$ & 100 & 99.4 & 76.7 & 100.0 & 95.2 & 86.2 \\
\hline Sample 18 & Gastroscopy & Dec. 2018 & $M / 57$ & 100 & 99.4 & 76.7 & 99.7 & 95.0 & 86.5 \\
\hline Sample 19 & Gastroscopy & Dec. 2018 & $F / 53$ & 100 & 99.4 & 76.7 & 99.5 & 94.7 & 85.8 \\
\hline Sample 20 & Gastroscopy & Jun. 2017 & $F / 31$ & 100 & 99.4 & 76.7 & - & - & - \\
\hline
\end{tabular}

-, data not available. 
tion with UV light. Automated DNA sequencing experiments on all ITS or cox2 PCR products were performed at Macrogen Co. Ltd. (Seoul, Korea). Nucleotide sequences obtained from each of the 2 isolates were aligned using the Geneious software version 10.2.6 (http://www.geneious.com) [11].

According to the PCR-RFLP results, the product from PCRamplified ITS region revealed an approximately 1,000 bp sized band for all samples, and RFLP patterns using Hinfl restriction enzyme presented A. pegreffii as 3 different fragments, $250 \mathrm{bp}$, $300 \mathrm{bp}$, and $350 \mathrm{bp}$, and Hysterothylacium aduncum as 2 differ-

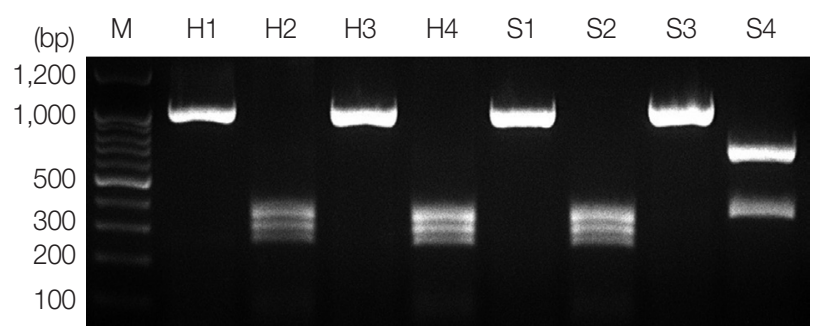

Fig. 1. PCR-RFLP analysis of ITS region for molecular identification of anisakid larvae. Each PCR product was digested with Hinfl and analyzed on $2 \%$ agarose gel. Sample $\mathrm{H} 1$ and $\mathrm{H} 3$, genomic DNA of Anisakis spp. from humans; $\mathrm{H} 2$ and $\mathrm{H} 4$, A. pegreffii (250, 300, and 350 bp); S1 and S3, genomic DNA of Anisakis spp. from the sea eel; S2, A. pegreffii (370 and 650 bp); S4, H. aduncum; M, 100-bp ladder.

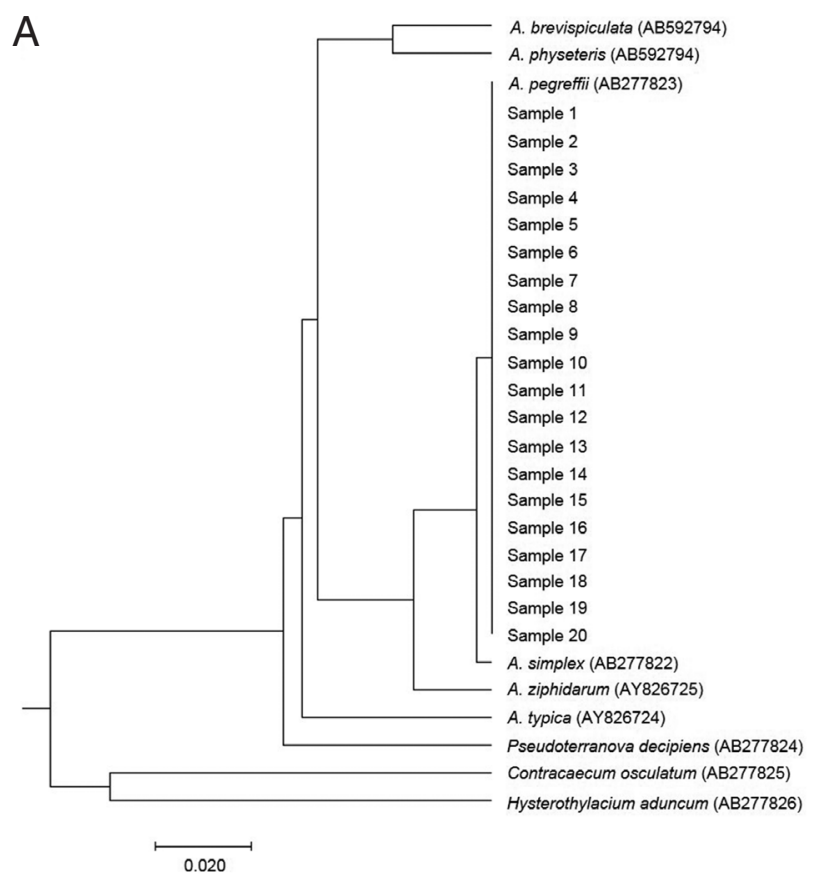

ent fragments, $370 \mathrm{bp}$ and $650 \mathrm{bp}$ (Fig. 1) [12]. A hybrid form of A. simplex s.s. and A. pegreffii reported in Iberian Peninsula [13] and Japan [14] showing 4 bands (620 bp, 370 bp, 300 bp, and $250 \mathrm{bp}$ ) using Hinfl restriction enzyme was not detected in this study.

We also confirmed the species-identification using sequencing of the ITS and cox2. All Anisakis larvae samples removed from humans showed 100\% identity with A. pegreffii (AB277823) and 99.4\% with A. simplex (AB277822) in a sequence of the ITS region (311 bp). In cox2 (378 bp) sequencing, the samples revealed 97.9-100\% identity with A. pegreffiii (EU413958) and 94.796.6\% with A. simplex (AB517560) (Table 1).

In the case of anisakid larvae from the sea eel, most samples (49 of 54 larvae; 90.7\%) were shown to be A. pegreffii with $100 \%$ identity in ITS region (608 bp) and $96.9-100 \%$ identity in cox2 (511 bp) (Table S1), while the others $(5 / 54 ; 9.3 \%)$ were H. aduncum representing 100\% identity (AB277826) in ITS region ( $877 \mathrm{bp}$ ) and $97.1-98.1 \%$ identity (KT439397) in cox2 region (582 bp).

For visualizing the evolutionary relationships among these larval samples from humans, UPGMA phylogenetic trees were obtained by nuclear rDNA ITS and mtDNA cox2 sequence, including anisakid nematodes, using Molecular Evolutionary

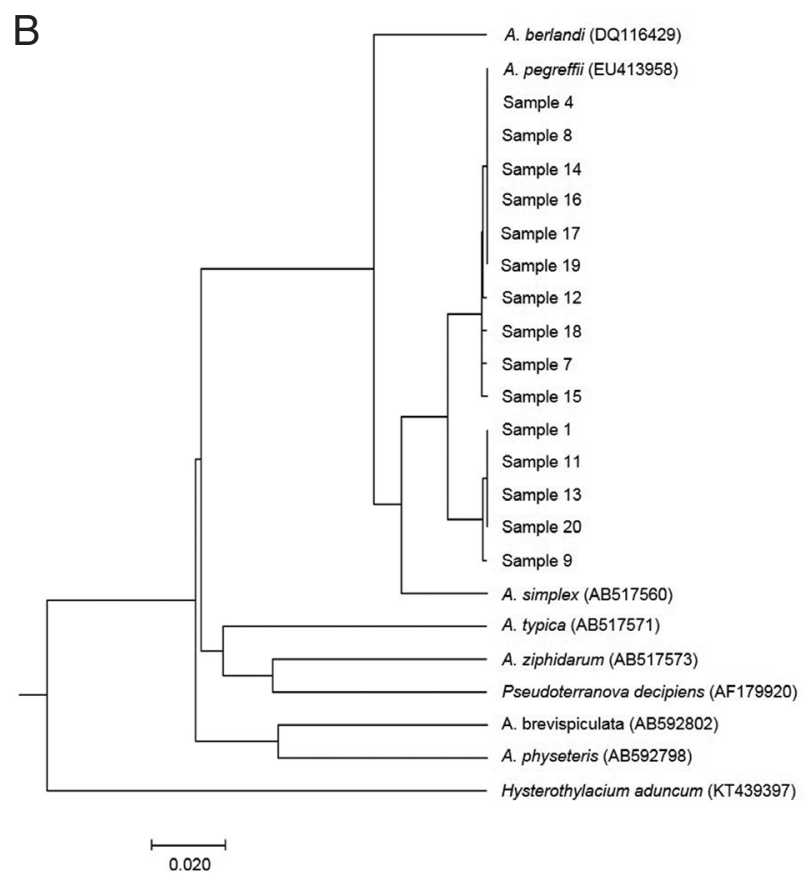

Fig. 2. Phylogenetic trees showing the genetic relationship of anisakid genera. Phylogenetic trees were analyzed with Anisakis larvae from humans and reference sequences from GenBank. The trees were constructed by the UPGMA using MEGA-X based on (A) ITS region (311 bp) and (B) cox2 gene (378 bp). The scale bar represents the evolutionary distance. 
Genetics Analysis version X (MEGA-X) software (Fig. 2). All our samples from human cases were clearly nested within the phylogenetic position of A. pegreffii analyzed by rDNA ITS (Fig. 2A) and mitochondrial cox2 (Fig. 2B).

Anisakiasis is one of the most important public health problems causing symptomatic infections in humans consuming raw or undercooked parasitized marine fish or cephalopods $[2,3]$. A. simplex is the most common species throughout the world including Japan where over $90 \%$ of worldwide anisakiasis cases have been reported [15]. In Korea, Anisakis type I (inclusive of A. simplex and A. pegreffii) has been the predominant larval type extracted from humans according to previous information [16]. However, in our previous study [8] and also in this study, it has been confirmed that A. pegreffii is the predominant species of anisakid larvae infecting humans in Korea. This is a remarkably contrasting result from Japan, where A. simplex s.s. has been the major species infecting humans $[14,17]$. The major reason for this difference between Korea and Japan seems to be different kinds of fish consumed by the people harboring different species of anisakid larvae.

In this study, we confirmed that the most $(90.7 \%)$ of the anisakid larvae from the sea eel were A. pegreffii, which is along with our results from human cases. The remaining 5 larvae (9.3\%) were H. aduncum. The RFLP patterns digested with Hinfl were similar between A. typica and H. aduncum with 2 different fragments 600-700 bp and 300-400 bp. However, rDNA or mtDNA gene sequencing made this identification clear (100\% identity in ITS region and $97.1-98.1 \%$ identity in cox2). Anisakis type I has been known to be the main larval type in the sea eel in Korea; however, A. pegreffii had been rarely documented in earlier studies [18]. According to a recent study, Cho et al. [18] clarified that the major species of anisakid larvae in the sea eel in Korea was A. pegreffii to which our results fully agree.

H. aduncum, another Anisakidae species, is regularly found in Mediterranean fish [19]. However, few reports have been available regarding this species from marine fish in Korea other than a report of Hysterothylacium sp. found in the chub mackerel (Scomber japonicus) [20] and largehead hairtail (Trichiurus japonicus) [21]. We have for the first time confirmed H. aduncum infection in the sea eel using a molecular technique in Korea. The possibility of human infections with $H$. aduncum needs to be elucidated.

Sporadic cases of human anisakiasis have been occurring continuously all over the world. Our study showed that A. pe- greffii is predominant for human anisakiasis in Korea. The primary treatment of anisakiasis is endoscopic removal of the worm, and there is no specific medication. Prevention is the best way through avoiding ingestion of raw seafood or well cooking or deep-freezing of the seafood before consumption.

\section{ACKNOWLEDGMENTS}

We thank the staff and medical doctors of Korea Association of Health Promotion who kindly cooperated in collection of anisakid larvae extracted from the health check-up patients under gastrointestinal endoscopy during 2017 and 2019. We also thank our staff Mr. Geun-Hoon Lee and Ms. Sooji Hong of Institute of Parasitic Diseases, Korea Association of Health Promotion, Seoul, Korea for their kind cooperation. This research was supported by a grant from Ministry of Food and Drug Safety in 2017-2019 (17162MFDAS034) and also by a Hallym University Research Fund (HRF-201610-011) of which the recipient was Sun Huh.

\section{CONFLICT OF INTEREST}

We have no conflict of interest related to this work.

\section{REFERENCES}

1. Shin EH, Guk SM, Kim HJ, Lee SH, Chai JY. Trends in parasitic diseases in the Republic of Korea. Trends Parasitol 2008; 24: 143-150.

2. Sohn WM, Chai JY. Anisakiosis (Anisakidosis). In Palmer SR, Soulsby L, Torgerson PR, Brown WG, eds, Oxford Textbook of Zoonoses-Biology, Clinical Practice, and Public Health Control. 2nd ed. Oxford, UK. Oxford University Press. 2011, pp 774-786.

3. Chai JY, Murrell KD, Lymbery AJ. Fish-borne parasitic zoonoses: status and issues. Int J Parasitol 2005; 35: 1233-1254.

4. Nieuwenhuizen NE. Anisakis - immunology of a foodborne parasitosis. Parasite Immunol 2016; 38: 548-557.

5. Im KI, Shin HJ, Kim BH, Moon SI. Gastric anisakiasis cases in Cheju-do, Korea. Korean J Parasitol 1995; 33: 179-186.

6. Choi SC, Lee SY, Song HO, Ryu JS, Ahn MH. Parasitic infections based on 320 clinical samples submitted to Hanyang University, Korea (2004-2011). Korean J Parasitol 2014; 52: 215-220.

7. Noh JH, Kim B, Kim SM, Ock M, Park MI, Goo JY. A case of acute gastric anisakiasis provoking severe clinical problems by multiple infection. Korean J Parasitol 2003; 41: 97-100.

8. Lim H, Jung BK, Cho J, Yooyen T, Shin EH, Chai JY. Molecular diagnosis of cause of anisakiasis in humans, South Korea. Emerg Infect Dis 2015; 21: 342-344. 
9. D’Amelio S, Mathiopoulos KD, Santos CP, Pugachev ON, Webb SC, Picanço M, Paggi L. Genetic markers in ribosomal DNA for the identification of members of the genus Anisakis (Nematoda: Ascaridoidea) defined by polymerase-chain-reaction-based restriction fragment length polymorphism. Int J Parasitol 2000; 30: 223-226.

10. Nadler SA, Hudspeth DS. Phylogeny of the Ascaridoidea (Nematoda: Ascaridida) based on three genes and morphology: hypotheses of structural and sequence evolution. J Parasitol 2000; 86: 380-393.

11. Kearse M, Moir R, Wilson A, Stones-Havas S, Cheung M, Sturrock S, Buxton S, Cooper A, Markowitz S, Duran C, Thierer T, Ashton B, Meintjes P, Drummond A. Geneious Basic: an integrated and extendable desktop software platform for the organization and analysis of sequence data. Bioinformatics 2012; 28: 1647-1649.

12. Vardić Smrzlić I, Valić D, Kapetanović D, Kurtović B, Teskeredžić E. Molecular characterisation of Anisakidae larvae from fish in Adriatic Sea. Parasitol Res 2012; 111: 2385-2391.

13. Abollo E, Paggi L, Pascual S, D’Amelio S. Occurrence of recombinant genotypes of Anisakis simplex s.s. and Anisakis pegreffii (Nametoda: Anisakidae) in an area of sympatry. Infect Genet Evol 2003; 3: 175-181.

14. Arai T, Akao N, Seki T, Kumagai T, Ishikawa H, Ohta N, Hirata N, Nakaji S, Yamauchi K, Hirai M, Shiratori T, Kobayashi M, Fujii H, Ishii E, Naito M, Saitoh SI, Yamaguchi T, Shibata N, Shimo M,
Tokiwa T. Molecular genotyping of Anisakis larvae in middle eastern Japan and endoscopic evidence for preferential penetration of normal over atrophic mucosa. PLoS One 2014; 9: e89188.

15. Hochberg NS, Hamer DH. Anisakidosis: perils of the deep. Clin Infect Dis 2010; 51: 806-812.

16. Sohn WM, Na BK, Kim TH, Park TJ. Anisakiasis: report of 15 gastric cases caused by Anisakis type I larvae and a brief review of Korean anisakiasis cases. Korean J Parasitol 2015; 53: 465-470.

17. Umehara A, Kawakami Y, Araki J, Uchida A. Molecular identification of the etiological agent of the human anisakiasis in Japan. Parasitol Int 2007; 56: 211-215.

18. Cho J, Lim H, Jung BK, Shin EH, Chai JY. Anisakis pegreffii larvae in sea eels (Astroconger myriaster) from the South Sea, Republic of Korea. Korean J Parasitol 2015; 53: 349-353.

19. De Liberato C, Bossù T, Scaramozzino P, Nicolini G, Ceddia P, Mallozzi S, Cavallero S, D’Amelio S. Presence of anisakid larvae in the European anchovy, Engraulis encrasicolus, fished off the Tyrrhenian coast of central Italy. J Food Prot 2013; 76: 16431648.

20. Bak TJ, Jeon $\mathrm{CH}$, Kim JH. Occurrence of anisakid nematode larvae in chub mackerel (Scomber japonicus) caught off Korea. Int J Food Microbiol 2014; 191: 149-156.

21. Kim JH, Nam WH, Jeon CH. Genetic identification of anisakid nematodes isolated from largehead hairtail (Trichiurus japonicus) in Korea. Fish Aquat Sci 2016; 19: 26. 
Supplementary Table S1. Nucleotide identity (\%) of Anisakis spp. larvae from the sea eel with Anisakis pegreffii, A. simplex s.s., and A. typica by gene sequencing

\begin{tabular}{|c|c|c|c|c|c|c|}
\hline \multirow[b]{2}{*}{ Sample no. } & \multicolumn{3}{|c|}{ ITS region } & \multicolumn{3}{|c|}{ cox2 } \\
\hline & $\begin{array}{l}\text { A. pegreffii } \\
\text { (AB277823) }\end{array}$ & $\begin{array}{c}\text { A. simplex } \\
\text { (AB277822) }\end{array}$ & $\begin{array}{c}\text { A. typica } \\
\text { (AY826724) }\end{array}$ & $\begin{array}{l}\text { A. pegreffii } \\
\text { (EU413958) }\end{array}$ & $\begin{array}{l}\text { A. simplex } \\
\text { (AB517560) }\end{array}$ & $\begin{array}{c}\text { A. typica } \\
\text { (AB517571) }\end{array}$ \\
\hline A 2 & 100 & 99.7 & 74.2 & 100.0 & 94.7 & 86.5 \\
\hline A 3 & 100 & 99.7 & 74.2 & 98.2 & 95.5 & 86.5 \\
\hline A 4 & 100 & 99.7 & 74.2 & 99.6 & 94.7 & 86.9 \\
\hline A 5 & 100 & 99.7 & 74.2 & 98.2 & 95.5 & 86.5 \\
\hline A 6 & 100 & 99.7 & 74.2 & 98.2 & 95.5 & 86.5 \\
\hline A 7 & 100 & 99.7 & 74.2 & 99.0 & 94.2 & 85.9 \\
\hline A 8 & 100 & 99.7 & 74.2 & 97.5 & 95.1 & 86.5 \\
\hline A 9 & 100 & 99.7 & 74.2 & 99.2 & 94.5 & 86.2 \\
\hline A 10 & 100 & 99.7 & 74.2 & 99.4 & 94.5 & 86.5 \\
\hline A 11 & 100 & 99.7 & 74.2 & 100.0 & 94.7 & 86.5 \\
\hline A 12 & 100 & 99.7 & 74.2 & 99.6 & 94.3 & 86.4 \\
\hline A 13 & 100 & 99.7 & 74.2 & 99.4 & 94.9 & 86.4 \\
\hline A 14 & 100 & 99.7 & 74.2 & - & - & - \\
\hline A 15 & 100 & 99.7 & 74.2 & 96.9 & 94.7 & 85.8 \\
\hline A 16 & 100 & 99.7 & 74.2 & 100.0 & 94.7 & 86.5 \\
\hline A 17 & 100 & 99.7 & 74.2 & 99.6 & 94.7 & 86.5 \\
\hline A 18 & 100 & 99.7 & 74.2 & 100.0 & 94.7 & 86.5 \\
\hline A 19 & 100 & 99.7 & 74.2 & 100.0 & 94.7 & 86.5 \\
\hline A 20 & 100 & 99.7 & 74.2 & 100.0 & 94.7 & 86.5 \\
\hline A 22 & 100 & 99.7 & 74.2 & 100.0 & 94.7 & 86.5 \\
\hline A 23 & 100 & 99.7 & 74.2 & 99.8 & 94.5 & 86.4 \\
\hline A 24 & 100 & 99.7 & 74.2 & 100.0 & 94.7 & 86.5 \\
\hline A 26 & 100 & 99.7 & 74.2 & 100.0 & 94.7 & 86.5 \\
\hline A 27 & 100 & 99.7 & 74.2 & 100.0 & 94.7 & 86.5 \\
\hline A 28 & 100 & 99.7 & 74.2 & 100.0 & 94.7 & 86.5 \\
\hline A 29 & 100 & 99.7 & 74.2 & 100.0 & 94.7 & 86.5 \\
\hline A 30 & 100 & 99.7 & 74.2 & 98.0 & 95.3 & 86.7 \\
\hline A 31 & 100 & 99.7 & 74.2 & 99.2 & 94.4 & 85.9 \\
\hline A 32 & 100 & 99.7 & 74.2 & 99.8 & 94.5 & 86.7 \\
\hline A 33 & 100 & 99.7 & 74.2 & 99.8 & 94.5 & 86.4 \\
\hline A 35 & 100 & 99.7 & 74.2 & 98.2 & 95.5 & 86.5 \\
\hline A 36 & 100 & 99.7 & 74.2 & 98.2 & 95.5 & 86.5 \\
\hline A 37 & 100 & 99.7 & 74.2 & 99.8 & 94.5 & 86.4 \\
\hline A 38 & 100 & 99.7 & 74.2 & 98.2 & 95.5 & 86.5 \\
\hline A 39 & 100 & 99.7 & 74.2 & 99.8 & 94.5 & 86.7 \\
\hline A 40 & 100 & 99.7 & 74.2 & 98.2 & 95.5 & 86.5 \\
\hline A 41 & 100 & 99.7 & 74.2 & 98.2 & 95.5 & 86.5 \\
\hline A 42 & 100 & 99.7 & 74.2 & 99.6 & 94.7 & 86.2 \\
\hline A 43 & 100 & 99.7 & 74.2 & 97.8 & 95.5 & 86.7 \\
\hline A 44 & 100 & 99.7 & 74.2 & 98.2 & 95.5 & 86.5 \\
\hline A 45 & 100 & 99.7 & 74.2 & 98.2 & 95.5 & 86.5 \\
\hline A 46 & 100 & 99.7 & 74.2 & 100.0 & 94.7 & 86.5 \\
\hline A 47 & 100 & 99.7 & 74.2 & 99.8 & 94.9 & 86.4 \\
\hline A 48 & 100 & 99.7 & 74.2 & 100.0 & 94.7 & 86.5 \\
\hline A 49 & 100 & 99.7 & 74.2 & 98.2 & 95.5 & 86.5 \\
\hline A 51 & 100 & 99.7 & 74.2 & 99.4 & 95.3 & 86.2 \\
\hline A 52 & 100 & 99.7 & 74.2 & 100.0 & 94.7 & 86.5 \\
\hline A 53 & 100 & 99.7 & 74.2 & 98.0 & 95.3 & 86.4 \\
\hline A 54 & 100 & 99.7 & 74.2 & 100.0 & 94.7 & 86.5 \\
\hline
\end{tabular}

Sample nos. A1, A21, A25, A34, A50 turned out to be Hysterothylacium aduncum by PCR-RFLP and sequencing analyses (data not shown). -, data not available. 